\title{
LA VOLATILIDAD DE LOS LEGADOS INDIANOS. EL CASO DE RUY DÍAZ RAMÍREZ DE QUIÑONES Y SUS DISPOSICIONES TESTAMENTARIAS
}

\author{
$M^{\mathrm{a}}$ Isabel VIFORCOS MARINAS \\ Universidad de León
}

\begin{abstract}
RESUMEN: Tomando como base el testamento del leonés Ruy Díaz Ramírez de Quiñones, emigrado a Tierra Firme en el último cuarto del siglo XVI, se busca, en este artículo un triple objetivo:primero, señalar la pervivencia de vínculos afectivos y materiales con su tierra de origen, más allá de la distancia espacial y temporal; segundo, destacar el deseo de que su memoria se vincule a obras benéfico-asistenciales, a favor de sus familiares y antiguos convecinos; y tercero, incidir en las dificultades de materialización de las fundaciones, porque pese a la normativa sobre bienes de difuntos, éstos o no llegaban a su destino o lo hacían tan disminuidos por los pleitos y los años, que las hacían inviables.
\end{abstract}

PALABRAS CLAVE: Testamento, Panamá, León (España), siglo XVI, historia social.

ABSTRACT: Taking the will of the leonine, Ruy Diaz Ramirez de Quiñones, who emigrated to Panama in the last quarter of the XVI century as its basis, this article has a triple objective. First to indicate the permanent and material links with his native country. Second to emphasise his desire that he be remembered by his relatives and former fellow citizens through his charitable works. Thirdly to reflect on the difficulties of foundations, because in spite of the norm on goods of deceased, these or they did not arrive at their destiny, or they did it so diminished by the lawsuits and the years, that made them nonviable.

KEYWORDS: Panamá, León (Spain), $16^{\text {th }}$ century, social history.

Rara es la historia local o regional en la que no hay un capítulo o, cuando menos un recuerdo, dedicado a aquellos afortunados que, habiéndose trasladado a Indias en busca de nuevos y mejores horizontes socio-económicos, hicieron llegar a sus familias, ydeudos alguna dádiva o beneficio, como muestra de su éxito ${ }^{1}$.

${ }^{1}$ Una muestra de la frecuencia de estos envíos puede verse en $\mathrm{M}^{\mathrm{a}}$ del C. MARTínEZ MARTíneZ y Ma José Espinosa Moro (1993), «Fundaciones con dinero americano en Castilla y León»,en Los castellanos y leoneses en la empresa de las Indias, T. I, Junta de Castilla y León, pp. 353-361. 
Ciñéndonos al ámbito leonés, tenemos legados americanos que, en ocasiones, se materializaron en grandiosos edificios, como el colegio e iglesia que bajo la titularidad de la Compañía de Jesús se levanta en Villafranca, en el siglo XVII, con el aporte económico de don Gabriel de Robles, tallador mayor de la casa de la moneda de Potosíi ; el seminario carmelitano que en el siglo XVIII dotó en Valderas el obispo payanés fray Mateo Panduro y Villafañe $e^{3}$ o los espléndidos claustros que en esa misma centuria se erigen en San Isidoro de León con la ayuda de las rentas de diversas sedes vacantes de diócesis americanas, concedidas en 1728 y hábilmente gestionadas por el que fuera su abad, el arzobispo de México D. Manuel Rubio y Salinas ${ }^{4}$. Otras veces se concretan en presentes como los remitidos por el arzobispo de Chiapas Francisco Bravo de la Serna al cabildo catedral, del que él había formado parte como canónigo y arcediano de Valderas ${ }^{5}$; como el plato y copa mexicanos, que hoy se conservan en el museo isidoriano, siendo conocidos como "la plata de Salinas" en directa alusión a quien se considera su donador ${ }^{6}$, o como el Cristo de Vilela que preside el panteón de los marqueses de Villafranca en la iglesia conventual de las clarisas de la Anunciada de esa localidad ${ }^{7}$.

Ruy Díaz Ramírez de Quiñones quiso también dejar constancia, en sus tierras leonesas, de la fortuna conseguida en Panamá y lo hizo a través de sus disposiciones testamentarias. Sin embargo su caso ilustra otra realidad sobre la que apenas se ha reflexionado, la de aquellos cuyos bienes quedarían diluidos tras su muerte en una maraña de deudas y pleitos que convirtieron sus últimas voluntades en quimeras irrealizables. Esta situación, que se va revelando como nada

2 Ma D. CAMPOS SÁncheZ-Bordona, (1994), «Fundación y construcción del colegio de la Compañía de Jesús en Villafranca del Bierzo», Tierras de León, 95 y 96, Excma. Diputación Provincial de León, pp. 59-81.

3 J. Fuentes Santamarta, (1984), El colegio seminario de San Mateo de Valderas, León, Excma. Diputación Provincial de León.

4 J. PÉREZ LlamaZARES, (1982), Historia de la real colegiata de San Isidoro de León, ed. facsímil de la editorial Nebrija, p. 194. Sobre los claustros: E. Morais VALLEJo, (2000), Aportación al barroco en la provincia de León. Arquitectura religiosa, Universidad de León, pp. 268-274.

${ }^{5}$ Ma I. Viforcos Marinas, (2002), «Carta del obispo de Chiapas Marcos Bravo de la Serna al cabildo de Regla. Una muestra de documentación epistolar» en La documentación para la investigación, vol. II, Universidad de León, pp. 657-673.

6 J. PAniagua PÉrez, (2004), «Universitarios leoneses en América», Hacia la Universidad de León. Estudios de Historia de la educación en León, Universidad de León, p. 354.

${ }^{7}$ Ma ARIAS JATO, (1996), «La fundación del monasterio de la Anunciada y su iglesia (16061653)», Claustros leoneses olvidados. Aportaciones al monacato femenino, Universidad de León, pp. 357-368 y J. PANiAgUA PÉREZ, (1994), Rincones americanistas leoneses Universidad de León, pp. 8790. 
excepcional, nos debería obligar a ser más cautos a la hora de atribuir a capitales provenientes de América la realización de fundaciones y construcciones, sin que ello signifique negar la importancia de algunas fortunas repatriadas ${ }^{8}$.

\section{RUY DÍAZ RAMÍREZ DE QUIÑONES: NOTAS BIOGRÁFICAS}

No son muchos los datos que conocemos sobre su persona, pues prácticamente se limitan a los que nos aportan sus testamentos y codicilos, la últimas voluntades de su esposa y un pleito movido por el monasterio cisterciense de Gradefes contra sus bienes. Por sus apellidos es obvio que estuvo entroncado con grandes linajes, aunque esta circunstancia, lejos de facilitar el rastreo de su persona, se convierte en dificultad añadida por el baile de apellidos, ya que se tiende a elegir y preservar no el del parentesco más cercano, sino el considerado más digno y de mayor categoría, y por el reducido abanico de nombres que suelen barajarse entre los miembros del linaje?

Fueron sus progenitores Diego Ramírez de Quiñones y Ana Ramírez de Arellano, vecinos de León, donde también debieron estar avecindados sus abuelos Ruy Díaz Ramírez y Beatriz de Quiñones. Los apellidos familiares proclaman su condición hidalga y su relativamente temprana vinculación a la empresa americana. Sobradamente conocido es el frondoso y ramificado árbol de los Quiñones, al que le vincula su abuela paterna, pues la leyenda hace remontar su antigüedad nada

${ }^{8}$ Sobre la importancia de los envíos del Nuevo Mundo, a nivel general: C. A. GONZÁLEZ SÁNCHEZ (1991), Repatriación de capitales del virreinato del Perú en el siglo XVI, Banco de España. Estudios de Historia Económica, No 20, Madrid; estudios sobre localidades concretas: J. ORTIZ DE LA TABLA (1985), «Rasgos socioeconómicos de los emigrantes a Indias. Indianos de Guadalcanal: sus actividades en América y sus legados en la metrópoli. Siglo XVII», en Andalucía y América en el siglo XVII, T. I, Sevilla, y (1971) «Emigración a Indias y fundación de capellanías en Guadalcanal, siglos XVI-XVII» en Actas de las Primeras Jornadas de Andalucía y América, Sevilla-La Rábida, pp. 441-460; A. GARCÍA-ABÁSOlo (1983), «Inversiones indianas en Córdoba. Capellanías y patronatos como entidades financieras», en Actas de las II Jornadas de Andalucía y América, T. I, Sevilla y A. L. González Rodríguez y L. V. Pelegri Pedrosa, «Capitales indianos en Castuera (Badajoz). Censos y fundaciones, 1660-1669» en Actas del IX Congreso Internacional de Historia de América, Sevilla, 1992, pp. 293-320; P. GALERA ANDREU (1994) «El oro americano y la financiación artística en el antiguo reino de Granada» en El reino de Granada y el Nuevo Mundo, T. 2, Diputación provincial de Granada, pp. 341-351 y A. MATEO PÉREZ, (1996), «Alaveses en Indias: Su repercusión social y artística en Álava», Álava y América, Vitoria-Gasteiz, pp.105-131.

9 De esta circunstancia se hace eco M. Torre Sevilla (1992), refiriéndose al linaje de los Quiñones, aunque desde luego no es específico de esta familia nobiliaria («Los Quiñones, señores de Quintanilla de Sollamas y del solar antiguo de San Román de los Caballeros, conquistadores y gobernadores del virreinato del Perú». ASTORICA, 11, Centro de Estudios Astorganos Marcelo Macías, p.157. 
menos que al inicio de la era cristiana, aunque la historia sitúa su origen en Pedro Álvarez, nombrado merino mayor de Asturias por Sancho IV en 1285; de este tronco principal irían surgiendo las diferentes líneas familiares: la de los Condes de Luna, con Diego Fernández de Quiñones como primer titular; la de los Quiñones de Benavente, a partir de los descendientes de su hijo Hernando, que incorporan el apellido Díaz por su madre, doña Juana; o la de los señores de Alcedo y la de los Quiñones de Riolago, a partir de Álvaro Pérez de Quiñones, por reducirnos a las de mayor fuste ${ }^{10}$. E igualmente sabida es su temprana aparición en el Nuevo Mundo, donde hallamos Quiñones ya desde la primera mitad del siglo XVI en todas las latitudes, como bien ejemplifica: la presencia de un Antonio de Quiñones en Cuba en 1518, el mismo que como capitán de Hernán Cortes participaría en 1521 en la campaña mexicana y que encontraría la muerte en las Azores, viniendo como su procurador a España, en 1522; o la del grupo de Quiñones -Alonso, Suero, Antonio- en el Perú, a donde habían acudido acompañando al gobernador Vaca de Castro en los años $40^{11}$. Aunque quizá la vinculación de más relumbrón entre el Nuevo Mundo y los Quiñones leoneses fuera la que representa la capitulación matrimonial, en 1555, de una hija de Hernán Cortes, María, con Luis Vigil de Quiñones, heredero del condado de Luna ${ }^{12}$. Seguramente se confiaba en esta dote para materializar el sueño del palacio renacentista que por entonces edificaba la casa de Luna en la plaza a la que daba nombre su título, aunque, como en tantos otros casos, los capitales comprometidos no fueron fáciles de cobrar, de hecho en 1561, era necesario un nuevo concierto con Martín Cortes para tratar de hacer efectiva la deuda de la dote, y todavía en 1577 seguían sin entrar en las arcas de los Condes, los 100.000 ducados de la misma ${ }^{13}$.

${ }^{10}$ Sobre este linaje remitimos a los estudios del Marqués de AlCEDo Y DE SAN CARLos (1918), Los merinos mayores de Asturias (del apellido Quiñones) y su descendencia. Apuntes genealógicos, históricos y anecdóticos, Madrid, vol. I, Madrid, Sociedad Española de Artes Gráficas y C. ÁlvareZ Álvarez (1982), El Condado de Luna en la Baja Edad Media, León, Colegio Universitario. Filosofía y Letras y J. A. MARTín Fuertes (2000), Los Quiñones marqueses de Montevirgen linaje y archivo, León, Instituto Leonés de Cultura, especialmente pp. 15-30.

${ }^{11}$ Menciones sobre estas figuras y algunos otros Quiñones emigrados a América, pueden hallarse en Marqués de Alcedo Y De San Carlos, (1918), C. García (1946), Leoneses en América, León, pp. 14-16, Ma I. Viforcos Marinas y J. Paniagua Pérez (1991), El leonés don Cristóbal Vaca de Castro gobernador y organizador del Perú, Madrid, Hullera Vasco-Leonesa, Madrid, pp. 67-71 y M. TORRE SEVILla (1992), «Los Quiñones, señores de Quintanilla de Sollamas...», pp.157-190.

12 C. Álvarez Álvarez y J. A. Martín Fuertes (1977), Catálogo del Archivo de los Condes de Luna, León, Colegio Universitario de León, doc. 587.

${ }^{13}$ Sobre el palacio M $M^{\text {a }}$ D. CAMPOS SÁNCHEZ-BORdONA (2002), «León» en J. URREA (dir.), Casas y palacios de Castilla y León, Valladolid, Junta de Castilla y León, pp. 96-100; acerca de las 
En cuanto al linaje de los Ramírez de Arellano, al que está ligado por vía materna, nada desmerece ni en antigüedad ni en prestancia, pues, según la tradición, procede de la casa real de Navarra, siendo fundado por Sancho Sánchez, primer señor de la villa de Arellano e hijo de don Sancho Ramírez, hermano del rey don García; desde 1475 el tronco principal de los Ramírez de Arellano recibió, por concesión de los Reyes Católicos, el condado de Aguilar y una hija de su segundo titular, doña Juana Ramírez de Arellano, contraería matrimonio con Hernán Cortés en 1529, el mismo año que el Conquistador recibía el título del marques del Valle; reforzándose los lazos de la familia con México y con el marquesado del Valle, en 1578, su hijo, Martín Cortés, casó con Ana Ramírez de Arellano, su sobrina ${ }^{14}$.

Si no van erradas nuestras conjeturas la abuela de Ruy Díaz Ramírez de Quiñones, Beatriz, sería hija del matrimonio constituido por Diego de Quiñones y María de Quiñones, hija de Suero Velasco Pérez de Quiñones, señor de Alcedo. No conocemos toda la descendencia de este matrimonio, en la que entraría, además de su padre, Diego, su tío, Pedro Ramírez de Quiñones y sus tías Juana de Quiñones y Ana de Valderas ${ }^{15}$.

Se nos ha sugerido la posibilidad de que su padre Diego, fuera durante un tiempo administrador de los Condes de Luna ${ }^{16}$, dato que no hemos podido constatar, aunque sí su embarque en 1553 rumbo a Honduras, en calidad de mercader y con una licencia de dos años ${ }^{17}$. Más dilata y conocida sería la trayectoria de su tío Pedro, que en 1543 había sido nombrado oidor de la recién creada Audiencia de los Confines de Guatemala y Nicaragua ${ }^{18}$. Durante el desempeño de su cargo hubo de actuar de juez de residencia de los miembros de la

reclamaciones de la dote matrimonial de María Cortes: C. Álvarez Álvarez y J. A. Martín FUERTES (1977), Catálogo..., docs. 593, 654 y 657.

${ }^{14}$ Sobre el linaje Ramírez de Arellano: Alberto y Arturo GarCía CARRAFA (1956), Diccionario heráldico y genealógico de apellidos españoles y americanos, Madrid, T. 65, pp. 6-7. En cuanto a Hernán Cortés, puede encontrarse una bibliografía plenamente actualizada en $\mathrm{M}^{\mathrm{a}} \mathrm{C}$. MARTínEZ Martínez (2003), Hernán Cortés. Cartas y Memoriales, León, Junta de Castilla y León y Universidad de León.

15 Agradecemos las orientaciones facilitadas por Dña. Mirian Valcárcel García para localizar el posible entronque familiar de Ruy Díaz con el linaje de los Quiñones.

${ }^{16}$ Damos las gracias por la sugerencia a la doctora Margarita Torre Sevilla-Quiñones de León.

${ }^{17} \mathrm{M}^{\mathrm{a}}$ del Carmen MARTíNeZ Martínez (1993), La emigración castellana y leonesa al Nuevo Mundo, Junta de Castilla y León, vol. II, p. 274, registro 6225.

18 J. M. Vallejo García-Hevia (2004), «Los orígenes de una Audiencia indiana: La Real Audiencia y Chancillería de los Confines (1524-1564)», El gobierno de un mundo. Virreinatos y Audiencias en la América Hispánica, Cuenca, Universidad de Castilla-La Mancha, pp. 601-631. 
extinta Audiencia de Panamá, cuyos territorios jurisdiccionales habían quedado repartidos entre las recién creadas de Lima y Los Confines ${ }^{19} \mathrm{y}$, de hecho, a él correspondería el gobierno del Istmo de 1543 a 1545, en calidad de corregidor de Tierra Firme ${ }^{20}$, así como llevar el socorro solicitado, al licenciado la Gasca, para la pacificación del Perú ${ }^{21}$. Después de haber encausado a María Peñalosa, madre de los Contreras por su rebelión y por el asesinato del obispo nicaragüense Valdivieso en 1550 , regresaría a España ${ }^{22}$.

En 1553 volvía a su destino en la Audiencia de Los Confines y pocos meses después le seguía su mujer Isabel de Saavedra ${ }^{23}$. De este periodo conocemos únicamente su actuación contra los indios rebeldes de la selva lacandona en $1559^{24}$. Quizás como reconocimiento a estos servicios se le destina a Charcas, donde se había decidido fundar una Audiencia, por la lejanía de Lima y el incremento poblacional experimentado por el distrito tras la puesta en explotación de las minas de Potosí. Como regente desde 1559 y después, desde 1563, como presidente, permanecerá en la citada Audiencia hasta que en 1573, a raíz de la visita realizada a la Audiencia por el licenciado Pedro de Castro se le suspende en su oficio y se le destierra a perpetuidad de las Indias ${ }^{25}$. Duró poco la "perpetuidad", pues en 1579 se solicitaba ya su absolución, que se obtenía en 1580, año en que se le despachaba título de presidente de la Audiencia de Panamá ${ }^{26}$. Rumbo a su nuevo destino se embarcaría en 1582 y, seguramente, tras su estela iría su sobrino Ruy Díaz Ramírez

${ }^{19}$ Se conservan sus actuaciones como juez de residencia de los oidores Pedro de Villalobos y Lorenzo Paz de la Serna en AGI, Justicia, 370.

${ }^{20}$ Ma C. Mena García (1984), La sociedad de Panamá en el siglo XVI, Sevilla, Excma. Diputación provincial de Sevilla, p. 200.

${ }^{21}$ T. Hampe Martínez (1989), Don Pedro de la Gasca. Su obra política en España y América, Lima, Pontificia Universidad Católica del Perú, p. 121.

${ }^{22}$ E. SCHÄFER (2003), El Consejo real y supremo de las Indias, vol. II, Junta de Castilla y LeónMarcial Pons, p. 411. Sobre la rebelión de los Contreras en Nicaragua y la actuación de Ramírez de Quiñones, del que se dice que en un tiempo fue colaborador del despótico gobernador y padre de los rebeldes Rodrigo de Contreras, MARQués De Lozoya (1920), Vida del segoviano Rodrigo de Contreras, Editorial Católica toledana, Toledo, pp. 179-180.

${ }^{23}$ M del C. MARTínez MARTíneZ, (1993), La emigración castellana y leonesa..., pp. 274 y 301.

24 A. M ${ }^{\text {a }}$ Rocchietti, M. TAmagnini, A. Lodesero y M ${ }^{\mathrm{a}}$ L. Gili (2003), El retorno del manifiesto, Ñuke Mapüforla Get, pp. 5-6.

${ }^{25}$ AGI, Lima 568, L. 9, ff. 66v-68; Charcas 418, L. 1, ff. 1-2 y 26-66r y E. SCHÄFER, (2003), El consejo real..., p. 436.

${ }^{26}$ AGI, Indiferente 739, n.136 y 426, L. 26, f. 199. 
de Quiñones ${ }^{27}$. Esta vez la estancia americana no sería demasiado larga, pues en 1585 el contador Juan de Vivero se hacía eco de la noticia de su muerte ${ }^{28}$, a la que se sumaría, pocos meses después, la de su mujer y su hijo, Juan Ramírez, según el testimonio inserto en la reclamación interpuesta por su nuera, María de Ledesma, para que se hiciesen traer a Sevilla los bienes de la familia, por ser parte en la herencia ${ }^{29}$.

Cuando Ruy Díaz decide emprender la aventura americana, debía de ser ya una persona de edad madura. Dejaba tras de sí una esposa, Ana de Herrera, de la que únicamente conocemos las escasas noticias contenidas en su testamento, otorgado en Corbillos el 30 de abril de 1568, ante la inminencia de un parto que no debía de presentarse demasiado bien. Hija de doña Leonor de Quiñones y probablemente nieta de don Pedro de Quiñones y Quirós, señor de Alcedo y Villardefrades y doña Juana de Herrera, tenía por entonces al menos una hija, Antonia de Quiñones, a la que decide mejorar en caso de que el vástago esperado no fuera varón ${ }^{30}$. Desconocemos si Ana de Herrera falleció en ese momento, aunque es probable; no tenemos demasiadas noticias de la hija, de la que únicamente nos consta su ingreso en el monasterio de Gradefes, en el que era novicia en 1586; y tampoco sabemos cuántos descendientes hubo en el matrimonio, pero es posible que hubiera alguno más, pues Ruy Díaz, en su testamento, alude a la muerte de sus hijos, en plural. Aunque su madre parece por su testamento muy vinculada al monasterio de Otero de las Dueñas, a cuyo beneficio dispone algunos modestos legados, como una basquiña para la imagen de la Virgen titular, y una renta de 12 ducados para su prima, Isabel de Robles ${ }^{31}$, religiosa en él, la preferencia de la hija por el monasterio de Gradefes no resulta extraña. Ambos claustros eran cistercienses, y desde su fundación, en el XIII, el de Otero había mantenido cierta dependencia respecto a la comunidad y abadesa de Gradefes. En ese mismo monasterio era monja su prima Magdalena de Valderas y Quiñones ${ }^{32}$ y, además, hasta 1579 había sido abadesa en

${ }^{27}$ AGI, Indiferente 1952, L. 2, f. 48v; Panamá 33, N. 125; 237, L. 11, ff. 91v-96; y Pasajeros, L. 6. E. 4501 .

${ }^{28}$ AGI, Panamá 33, N. 125.

${ }^{29}$ La orden para que se remitan los bienes lleva fecha de 20 de marzo de 1586; en 1587 se despacha otra para que se haga efectivo a sus herederos el salario que se le adeudaba como presidente de la Audiencia. AGI, Panamá, 237, L. 12, ff. 53v-54r e Indiferente 527, L. 1, ff. 59v-60.

${ }^{30}$ Archivo Histórico Nacional (en adelante AHN), NoBLEZA, Fernánnúñez, leg. 683/7.

${ }^{31}$ AHN, NoBLEZA, Fernánnúñez, leg. 683/7.

32 Antonia de Quiñones o de Herrera, como prefiere su madre que apellide, menciona a Magdalena de Valderas, en la renuncia de bienes formalizada el 25 de febrero de 1586, como beneficiaria de una renta de 6.000 maravedíes anuales y un jarro de plata. ARCHIVO DE LA REAL 
él Ana Ramírez de Quiñones, sustituyéndola en ese año, Ana Quiñones Pimentel, apellidos que proclaman sobradamente la fuerza que en aquellos tiempos tenía el parentesco, a la hora de elegir los destinos personales ${ }^{33}$.

Desconocemos si cuando Ruy Díaz de Quiñones decidió viajar al Nuevo Mundo, su hija ya estaba recogida en el claustro, pues el único testimonio con el que contamos es la vaga alusión, hecha por ella al ceder todos sus bienes a la comunidad y pedir que se le diese la profesión en 1586, de que su padre hacía más de seis años que se hallaba ausente, tiempo durante el que no había tenido noticia alguna de su paradero ${ }^{34}$.Tampoco podemos aventurar con qué medios partió, pues únicamente tenemos noticia cierta de su destino, Tierra Firme, y de las licencias que se le otorgan para llevar con él dos espadas, dos dagas, un arcabuz y un criado $^{35}$. Sí hay indicios que apuntan a que su situación económica no debía ser demasiado desahogada. Su propia esposa, al otorgar testamento en 1564, había considerado imprescindible porque no se bea en pobreça y se pueda mantener con la honrra que yo deseo y a él pertenece, concederle el usufructo completo de sus bienes por todos los días de su vida ${ }^{36}$. El testamento no contiene ninguna alusión a la cuantía o tipo de hacienda objeto de la legación, aunque alguno de los testigos llamados a declarar con motivo del pleito que el monasterio de Gradefes movió, a la muerte de su hija, para hacerse con la herencia que consideraba pertenecerle, estima que la fortuna dejada por Ana de Herrera podía ascender a seis o siete mil ducados $^{37}$. Aun así Ruy Díaz no debía ir demasiado sobrado, porque el monasterio, en el citado pleito, denuncia el impago de los alimentos del periodo de noviciado y de la dote de profesión de su hija Antonia, y en su testamento él mismo menciona diversas deudas dejadas en su tierra al momento de partir, entre ellas, el valor de $u n$ macho que tomó a Zamora "el Mozo", más otro macho y una mula que le dio un vecino de León, cuyo nombre no recordaba, para su viaje a Sanlúcar, y las

Chancillería de Valladolid (en adelante ARChV), PL. Civiles. Pérez Alonso (F), caja 1006.0003.

${ }^{33}$ A. CAlvo (1984), El monasterio de Gradefes, León, Imprenta provincial, ed. facsímil, pp. 246254.

${ }^{34}$ ARCHV, PL. CiVILES. Pérez Alonso (F), caja 1006.0003.

${ }^{35}$ Para llevar las mencionadas armas se le da licencia por cédula despachada en Lisboa el 4 de junio de 1582, y en ese mismo mes y año, el día 18, se le otorga la del criado. AGI, Panamá 237, L. 11, f. 150r e Indiferente 1952, L. 2, f. 48v.

${ }^{36}$ AHN, NoBlEZA, Fernánnúñez,leg. 683/7.

${ }^{37}$ ARCHV, PL. CIVILES, Pérez Alonso (F.), 1006.0003. 
cantidades que constaren en el libro de cuentas que dejó en poder de Pedro de Quiñones, escribano de la ciudad ${ }^{38}$.

El destino elegido, Tierra Firme, era a priori idóneo para hacer fortuna, pues Panamá gozaba de fama como emporio mercantil, porque, en palabras de Alonso Criado de Castilla, es mucho el comercio y trato desta ciudad, ansí de las cosas de España como del Perú, por estar en medio de los dos mares del Norte y del Sur, y muy acomodada para las contrataciones ${ }^{39}$. Aún no se había disipado su notoriedad como centro aurífero, sostenida en el descubrimiento de las minas de Veragua, primero, y, posteriormente, en 1581, de las de Pequení, e igualmente se mantenía viva su reputación como zona de abundantes bancos de perlas. Era también propicia, en principio, la circunstancia en la que se producía la arribada de Ruy Díaz, a la sombra de Ramírez de Quiñones, presidente de la Audiencia, cuyo parentesco podía, sin duda, suponer la llave para introducirle en el complejo mundo de los tratos y contratos, dominado por un reducido grupo de vecinos, que controlaban, gracias al sistema de "oficios vendibles y renunciables", los resortes del poder local, utilizándolos en beneficio propio y de sus socios y parientes, entre los que se contaban diferentes mercaderes y cargadores sevillanos ${ }^{40}$.

Una vez en su destino, por lo que se infiere de su testamento, se dedicó a la principal y general ocupación y ganancia de los vecinos de Panamá, que no era otra que la contratación y comercio $^{41}$. A su muerte nos consta que tenía un barco explotado con esclavos negros para trajinar por el río Chagres, vía fluvial a través de la cual se transportaban las mercancías que iban y venían de Nombre de Dios a la Casa de Cruces, y desde ésta, a lomos de mula, hasta Panamá. Mantenía negocios de diversa índole con diferentes peninsulares, vinculados de una u otra forma al servicio de la Corona, y miembros de la oligarquía panameña. Entre ellos menciona a Luis Armas Perdomo, al que le ligaban ciertos lazos de familia, pues estaba casado con Mariana Ramírez de Quiñones, hija del leonés Bernardo

38 ARCHIVO SAN ISIDORO DE LEÓN (en adelante ASIL), S.a 258-18, s.f.

39 A. CRIAdo De CASTILla, Sumaria descripción del Reyno de Tierra Firme (1575), en O. JAÉN SUÁREZ (1985), Geografía de Panamá, Panamá, Universidad de Panamá, pp. 21-22.

${ }^{40}$ Sobre estos aspectos remitimos a Ma del C. Mena García (1984), La sociedad de Panamá en el siglo XVI, Sevilla, Excma. Diputación Provincial de Sevilla, especialmente pp. 222- 244 y 284-285 y A. Castillero Calvo (2004), «Historia y sociedad. Los grupos de poder en la colonia», Tareas, 116, Centro de Estudios Latinoamericanos, pp. 5-44.

${ }^{41}$ Así lo refleja la Relación de 1607. Vid. P. de VALEnCIA, Relaciones de Indias 1. Nueva Granada y Virreinato de Perú, en Obras completas V, ed. J. PANIAGuA PÉrez (1993), León, Universidad de León, p. 166. 
Ramírez de Quiñones, emigrado a Indias en $1576^{42}$. Armas Perdomo, pariente del licenciado López de Cepeda, que fuera oidor de Lima y presidente de las Audiencias de Panamá y Charcas, formaba parte del cabildo panameño en 1580, fecha en la que era ya contador, y se le tenía por persona entendida en la navegación marítima, razón por la que se había ocupado en más de una ocasión en el despacho y avituallamiento de los navíos despachados a Filipinas ${ }^{43}$. Por las alusiones a ajustes de cuentas contenidas en el testamento de Ruy Díaz, parece que, bien en calidad de socio o bien de persona interpuesta, había realizado con él algunas operaciones mercantiles con ropa, joyas y esclavos, enviados a Perú.

Tenía cuentas pendientes con Juana de Quiñones, a la que en ocasiones apellida también Osorio, como esposa de Pedro López de Baeza y tutora y curadora de su hijo Bernardo. López de Baeza era ya un acaudalado vecino de Panamá en 1575, año en el que su fortuna se calculaba en 12.000 ducados; desde 1584 desempeñaba el cargo de depositario general de la ciudad de Panamá y en los años siguientes se le cita entre los regidores de su cabildo ${ }^{44}$. Por lo que se deduce de las nunca claras alusiones del testamento de Ruy Díaz, utilizando capital propio y del depositario había hecho algunas operaciones crediticias de las que los herederos de López de Baeza, fallecido en 1590, reclamaban capital y beneficios ${ }^{45}$.

De más vuelos debían ser los vínculos societarios mantenidos con Alonso de la Torre. Cuando el licenciado de la Torre llegó a Panamá llevaba tras de sí una larga trayectoria como jurista, pues había sido fiscal de la Audiencia de Santa Fe entre 1564 y 1578, año en que fue nombrado oidor de la Audiencia de Santo Domingo, aunque parece que no tomó posesión, $\mathrm{y}$, después de pasar algún tiempo en la Península, fue destinado a la de Panamá, en $1584^{46}$. Sin tener para nada en cuenta la expresa prohibición de que los funcionarios trabaran relaciones con las elites locales e interviniesen en negocios para incrementar su peculio, el oidor se involucró en el negocio de las perlas, en sociedad con Ruy Díaz, contando con dos

${ }^{42}$ En el expediente y licencia de pasajero de Bernardo Ramírez y su extensa prole se dice que pasaba como portero de la Ciudad de Los Reyes, aunque en 1575 se le había nombrado tesorero de Nueva Castilla. AGI, Contratación, 5223, N. 30 y5792, L. 1, ff. 187-188.

${ }^{43}$ Los datos proceden de la información realizada en 1581: AGI, Panamá 33, N. 120; también hay referencias a su persona en AGI, Panamá, 33, N. 122, 124 y 151 y en $\mathrm{M}^{\mathrm{a}}$ del C. MenA(1984), La sociedad..., p. 279.

${ }^{44}$ AGI, Panamá, 62, N. 21 y 237, L. 12 y Ma del C. MENA (1984), La sociedad..., pp. 279 y 296.

${ }^{45}$ ASIL, S.a 258-18, s.f.

${ }^{46}$ E. SCHÄFER (2003), El Consejo real y supremo de las Indias, II, Junta de Castilla y León, pp. 387,407 y 436. 
bergantines -el San Francisco y el Santa Ana- con sus correspondientes arraeces y negros. El negocio, en el que también se hallaban invertidos capitales en depósito de Alonso de Maldonado y Baltasar de Jaén ${ }^{47}$, acabó en pleito, siendo condenado el oidor a la suspensión de oficio, por espacio de cuatro años -de 1593 a 1597- , y al pago de una multa de 500 ducados, mientras a su socio, Ruy Díaz, se le embargaban sus bienes ${ }^{48}$.

Aunque él no lo menciona en ninguno de los documentos de última voluntad, en la carta enviada por el licenciado Gaspar de Torres a la comunidad de San Isidoro, se alude también a ciertas vinculaciones económicas con don Álvaro Flórez de Quiñones, que había capitaneado las flotas a Nueva España y Tierra Firme en numerosas ocasiones en la década de los 80 , y de hecho el fiscal real había interpuesto pleito, en razón de algunos bienes pertenecientes al general, que Ruy Díaz retenía en su poder ${ }^{49}$.

La actividad mercantil desarrollada por el leonés debió de ser bastante intensa, pues él mismo confiesa tener cuenta con tres escribanos, Diego del Castillo, Francisco Ortiz y Núñez Bejarano ${ }^{50}$, con los que pide se ajusten cuentas, por las muchas escrituras que le han diligenciado.

Como era frecuente en aquellas latitudes, simultaneó sus negocios con algunos otros oficios, que si no daban beneficios económicos directos, si brindaban prestigio, relaciones y ocasiones indirectas de lucro. Dice en su testamento haber sido alguacil mayor de la Audiencia, pero debió desempeñar el cargo de forma interina, pues no hemos localizado prueba documental ninguna que avale la compra

47 Alonso de Maldonado era vecino de Panamá y estuvo asociado a Baltasar Jaén, vecino de Sevilla y maestre de una nao, que desde los años 60 había mantenido un activo comercio con Tierra Firme. La sociedad dio lugar a un pleito sobre la data de cuentas exigida por los herederos del sevillano, que se prolongó de 1590 a 1600. AGI, Escribanía, 448B y E. LoRENzo SANZ (1979), Comercio de España con América en la época de Felipe II, T. I, Diputación Provincial de Valladolid, p. 368.

${ }^{48} \mathrm{M}^{\mathrm{a}}$ del C. MENA, La sociedad...., p. 228 y ASIL, S.a 258-18, s.f.

49 ASIL, S.a 258-18, s.f; E. LoREnzo SANZ (1980), Comercio de España..., T. II, pp. 269-270, 286,290 y $344-345$.

${ }^{50}$ A los dos primeros se les menciona, en la relación de 1607, como compradores de las dos escribanías de provincia; Diego del Castillo la adquirió en 2.400 pesos a Diego de Sabogal, y Francisco Ortiz, en 2.000 pesos, a Baltasar Martínez. El segundo, que había visto confirmado su título de escribano real en Indias en 1589, hallándose en México, era titular de una escribanía en Portobelo, adquirida en 1500 pesos. AGI, México 173, N. 46 y Panamá 55, N. 70 y P. de Valencia, Relaciones de Indias 1. Nueva Granada y Virreinato de Perú, en Obras completas V, ed. J. PANiAguA PéreZ (1993), p. 173. 
de este oficio, aunque sí las hay de otros titulares del alguacilazgo, como Ventura Medina (1580), Juan Álvarez Vallejo (1583), Jerónimo de Zuazo (1585) o Francisco Terrín $(1598)^{51}$. Algún año fue también alcalde ordinario de la ciudad, y como tal se le menciona en el proceso abierto contra el oidor Alonso de la Torre ${ }^{52}$. Y el hecho de que el licenciado Gaspar de Torres se refiera a él con el tratamiento de capitán, unido a la licencia para portar armas, le involucra también en ciertas tareas de milicia, quizás relacionadas con la defensa de Panamá, siempre amenaza por los fenómenos de cimarronaje y piratería ${ }^{53}$.

¿Eran todas estas actividades suficientes para hacerse rico? La respuesta no puede ser categórica. No hay duda de que Ruy Díaz logró hacer alguna fortuna. Al barco del Chagres y la tripulación de negros esclavos, todo libre y sin hipotecas, hay que agregar como propiedad suya, la casa que poseía en Nombre de Dios. El valor de ésta no residiría seguramente en la calidad del inmueble, de madera, como el común del centenar que componía el caserío del puerto atlántico hacia 1585, sino en la pingüe renta que se podría obtener a partir de su arrendamiento durante el tiempo que la flota permanecía anclada en el puerto, pues los alquileres, dependiendo del tamaño de la vivienda y de la presión de la demanda, podían alcanzar los 800 pesos anuales, no bajando generalmente de los 500, eso sin contar el servicio que podía brindar como almacén de mercancías para los trajines en que se ocupaba Ruy Díaz ${ }^{54}$. Aunque en Panamá vivía de alquiler, pagando una renta de 20 pesos mensuales, tenía también casas propias, adquiridas al regidor Damián Méndez que se resistía a abandonarlas, a pesar de los 1.000 pesos recibidos ${ }^{55}$. A estos bienes materiales habría que añadir el capital invertido en los diferentes negocios, cuya cuantificación resulta imposible, porque apenas se dan cifras en su testamento y codicilo, en los que constantemente se remite a los libros de cuentas que obraban en su poder, y además desconocemos cuál era el grado de participación de Ruy Díaz en ellos.

No faltan, con todo, indicios que apuntan hacia una situación, cuando menos, desahogada. Así en el testamento formalizado en 1595, se habla de un jaez de oro, plata y perlas, confiado a Luis Osorio Quiñones, cuya venta en España podría

${ }^{51}$ ASIL, S.a 258-18, s.f. y Mª del C. MENA, La sociedad...., pp. 268-269.

${ }^{52} \mathrm{M}^{\mathrm{a}}$ del C. MenA, La sociedad...., p. 228.

53 ASIL, S.a 258-18, s.f. y Mª del C. MENA, La sociedad...., pp. 300-309.

${ }^{54}$ Sobre el caserío y la especulación de las fincas urbanas en Nombre de Dios: Ma del C. MENA (1992), La ciudad en un cruce de caminos (Panamá y sus origenes urbanos), Sevilla, Consejo Superior de Investigaciones Científicas, pp. 229-236.

${ }^{55}$ ASIL, S.a 258-18, s.f. 
suponer unos diez mil ducados, y su albacea menciona un collar de perlas que tenía en su poder un vecino de Panamá llamado Sebastián de la Puebla, valorado en seis o siete mil ducados, y estima el monto del capital que litigaba con el oidor Alonso de la Torre en unos veinte mil ducados ${ }^{56}$.

Terminaría de redondear su fortuna los legados de los que dice ser beneficiario, en condición de heredero: de su padre, Diego Ramírez de Quiñones, de su esposa, Ana de Herrera, de sus tíos Pedro y Juana Ramírez, de su primo Antonio Ramírez y del clérigo Cristóbal Lebrón de Quiñones ${ }^{57}$. Pero lamentablemente, de tanta manda testamentaria no hay más concreción que la que hace su albacea en la carta remitida al cabildo de San Isidoro, cifrando los bienes existentes en León en unas casas principales y una renta de unos 800 ducados, y advirtiendo de que parte de su fortuna se hallaba en poder de Antonio Rodríguez de Cabrera ${ }^{58}$. Era éste un comerciante sevillano, considerado un poderoso cargador de Tierra Firme, que había sido varias veces cónsul de la universidad de mercaderes de Sevilla y que en 1581 era uno de los ocho hombres de negocios, a los que se habían otorgado las rentas del almojarifazgo mayor de Sevilla y del de Indias ${ }^{59}$.

Enjuiciado con parámetros peninsulares, no hay duda de que Ruy Díaz Ramírez de Quiñones parecía dueño de una fortuna tan digna de consideración, que los canónigos isidorianos podían sentirse satisfechos por haber sido elegidos como herederos universales ${ }^{60}$. Hay que pensar que la fortuna de doña Leonor de Quiñones, nieta del primer Conde de Luna y sobrina de la fundadora del convento de las concepcionistas de León, ascendía en el momento de su muerte, en 1592, a poco más de 14.500 ducados, cantidad que se consideró más que suficiente para la fundación de unas memorias, que perdurarían hasta el siglo XIX, para permitir el acceso al monasterio de la Concepción de hasta tres monjas coristas, sufragar la sepultura de doña Leonor y su esposo en el coro. y dar limosnaa pobres vergonzantes de la ciudad, limosna que incluye una ayuda para casar huérfanas ${ }^{61}$.

\footnotetext{
${ }^{56}$ ASIL, S.a 258-18, s.f.

${ }^{57}$ ASIL, S.a 258-18, s.f.

58 ASIL, S.a 258-18, s.f.
}

${ }^{59}$ L. GARCía FuENTES (1997), Los peruleros y el comercio de Sevilla con las Indias, 1580-1630, Sevilla, pp. 265-267 y 297-298 y E. LoREnzo SANZ (1979), Comercio de España con América en la época de Felipe II...., T. I, pp. 171 y 395 y E. LoREnZo SAnZ (1980), Comercio de España..., T. II, p. 400.

${ }^{60}$ ASIL, Actas capitulares 1574-1600, I-e, 74-1 b, f. 477r.

${ }^{61}$ Sobre las citadas memorias: J. A. MARTín FuERTES (1996), «Las memorias y obras pías de Leonor de Quiñones. Una fundación del año 1592 a favor del monasterio de la Inmaculada 
Pero indudablemente el valor de los ducados no era el mismo en el lánguido marco de una ciudad como León, que afronta los últimos años del quinientos consumida por los envites del hambre y la peste, que en Panamá, donde también estaba siempre jugada la vida por la insalubridad de la zona, pero el dinero corría y se movía constantemente, al amparo de los negocios generados en torno al eje Nombre de Dios-Panamá, pues no en vano en el periodo $1580-85$, el 65\% de toda la plata y oro que llegó a la Península procedente de América, pasó por el Istmo ${ }^{62}$. En León, bastaban 500 ducados, después de la subida de 1567, para cubrir el salario del corregidor, y 600 fueron suficientes para mantener a los 300 infantes con los que la ciudad sirvió a Felipe II para la guerra con Portugal en $1580^{63}$. En Panamá los servicios anuales de un barbero, un médico o un escribiente superaban los 240 ducados, pues a su salario había de añadirse los gastos de manutención y alojamiento $^{64}$. En 1590, una libra de pan costaba en Panamá 68 maravedíes y un cuartillo de vino 136, mientras que en León, a finales de esa década, se compraban por 5 y 14 maravedíes respectivamente ${ }^{65}$. Esta abismal diferencia de precios y de nivel de vida justifica que en aquellas latitudes, Ruy Díaz Ramírez de Quiñones no figurara entre los vecinos considerados ricos, no sólo por el limitado volumen de su presumible fortuna, sino también, por hallarse ésta, en buena medida, al albur de los tiempos y de los pleitos. Los tiempos no fueron buenos en los últimos lustros del XVI, porque la llegada de las flotas se espaciaron, los ataques piráticos se incrementaron, los precios de las mercancías se dispararon, y la contratación de Nueva España y China distrajo buena parte de la plata proveniente del Perú, añadiéndose a estas adversas circunstancias, las dificultades de comunicación entre Nombre de Dios y Panamá, y las malas condiciones del puerto de Perico, a causa

Concepción de León», en Claustros leoneses olvidados. Aportaciones al monacato femenino, León, Universidad de León, pp. 217-225.

${ }^{62}$ El dato estadístico es de E. J. Hamilton, pero tomado de A. CASTILlero (1980), Economía terciaria y sociedad: Panamá siglos XVI y XVII, Panamá, Imprenta de la Nación, p. 9-11.

63 ArChivo Histórico Municipal De LeÓn (en adelante AHML), docs. 776, 782 y 824. Se cita por J. A. Martín Fuertes y C. Álvarez Álvarez (1982), Archivo Histórico Municipal de León. Catálogo de los documentos, publicado en León por el Excmo. Ayuntamiento de León.

${ }^{64}$ Los datos corresponden al informe elaborado por la Audiencia de Panamá sobre la carestía de

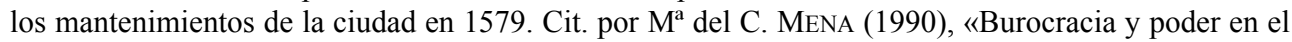
Panamá del Quinientos», Estudios de Historia social y económica, № 6, Alcalá de Henares, p. 15.

${ }^{65}$ Los datos de Panamá proceden de Cl. H. HARING (1979), Comercio y navegación entre España y las Indias en la época de los Habsburgos, México, Fondo de Cultura Económica, p. 234. y los de León del Archivo Histórico Diocesano de León, Fondo parroquial de San Marcelo, Libro de cuentas de fábrica (1598-1633), 797, f. 3. 
de las deficiencias de drenaje ${ }^{66} . Y$ los litigios fueron tantos y tan largos, que pocas fortunas podrían haber salido airosas de ellos, según se pondrá en evidencia a la muerte de Ruy Díaz, acaecida en Panamá, en septiembre de 1596, como testimonia el licenciado Gaspar de Torres, en su comparecencia ante el oidor Fernando Arias Ugarte, del día 20 de ese mes y año, para solicitar la apertura de su testamento ${ }^{67}$.

\section{LAS ÚLTIMAS VOLUNTADES: TESTAMENTOS Y CODICILO ${ }^{68}$}

El primer testamento, del que tenemos noticia, de Ruy Díaz Ramírez, se formalizó en Madrid, poco antes de partir para América; así lo afirma él mismo en el redactado el 24 de junio de 1595, manifestando que lo otorgó abrá más de doze años y quedó en poder del señor Juan de Ledesma. Antes de embarcarse, dispuso otro en Sanlúcar de Barrameda, que quedó en poder de Pedro de Estrada Morquecho. Y años más tarde, el 24 de junio de 1595, redactaba uno nuevo, cerrado, que serviría de base al definitivo, pues lo modifica el 8 de enero, añadiendo de nuevo los tres pliegos que van de otra tinta, hasta conformar las 15 hojas escritas de su mano, que entregó al escribano Diego de Castillo. En junio de 1595 gozaba de buena salud y nada dice de las razones que le impulsaron a la disposición de sus últimas voluntades; en las modificaciones de enero no se detiene en dar noticias sobre su estado físico, tal vez porque las redacta bajo la presión de las noticias sobre el inminente ataque de Drake, que el 6 de ese mes había llegado a Nombre de Dios y utilizando la vía del Chagres intentaba caer sobre Panamá ${ }^{69}$. Meses después, el 12 de septiembre, muy pocos días antes de su muerte, firmaba un codicilo con algunas enmiendas ${ }^{70}$.

Tanto el testamento de junio de 1595 como el codicilo de 1596 responden formal y jurídicamente al modelo regulado por las Partidas $^{71}$, que es el que se mantiene sin apenas variaciones hasta el fin del Antiguo Régimen. El de nuestro leonés se inscribe en el tipo de los llamados cerrados, ológrafos o in scriptis, por

\footnotetext{
${ }^{66}$ De la crisis finisecular del Istmo y de sus causas se hace amplio eco la Relación de 1607. P. de Valencia, Relaciones de Indias 1. Nueva Granada y Virreinato de Perú, en Obras completas V, ed. J. PANIAGUA PÉREZ (1993), pp. 167-169

${ }^{67}$ ASIL, S.a 258-18, s.f.

${ }^{68}$ Para evitar repeticiones de notas innecesarias, advertimos que el testamento y codicilo que se analiza se conserva en ASIL, S.a 258-18, s.f.

69 M. Lucena Salmoral (1992), Piratas, bucaneros, filibusteros y corsarios en América, Madrid, Mapfre, pp. 106-109 y 113-116.

${ }^{70}$ ASIL, S.a $258-18$, s.f.

${ }^{71}$ Partidas III, Tit. XVIII, leyes 102-104.
} 
estar redactado de su puño y letra y validado por siete testigos, que debían estampar su nombre en la cubierta, convenientemente cerrada y sellada, y reconocer su firma a la hora de su apertura. La única peculiaridad es la petición formulada por Ruy Díaz de que su testamento se considerase válido, aunque ninguno de los testigos firmante se hallase presente al abrirlo, en atención aser todos de las Indias y personas que tratan y van y vienen al Perú y a Castilla y a otras partes cada día ${ }^{72}$.

La invocación divina que sirve de encabezamiento al codicilo sigue la fórmula habitual -In dei nomine amen-, pero el testamento se aparta del modelo más usual, no sólo porque pospone la identificación del testador y el estado en el que testa, sino porque la hace una con la profesión de fe y la elección de intercesores. Tras insistir en la plena aceptación del dogma de la Trinidad y hacer protesta de querer vivir y morir bajo la fe que tiene, cree y confiesa la Santa Madre Iglesia Católica, elige por abogada a la Madre de Dios, a la que reconoce por siempre virgen, antes del parto y en el parto y después del parto, y a la que ruega, desconfiando de su natural: me tenga siempre de su mano, porque... si su divina magestad, me dexa della, como hombre tan pecador e tan flaco como soy, caeré en todas las miserias y pecados pusibles. Persistiendo en la desconfianza que le suscita su condición de pecador, concluye pidiendo amparo a la misericordia de Dios, para que le libre con los méritos de su santísima pasión y resurrección, la pena que yo, por mis culpas y pecados, merecía parecer.

El testamento de Ruy Díaz se aparta también de los modelos habituales en la preceptiva manifestación de la plena cordura del otorgante ${ }^{73}$, pues no se conforma con afirmar, de acuerdo a la fórmula habitual, que se halla: con todo mi juicio y entendimiento, según Nuestro Señor fue servido darme por su misericordia, sino que incluye al final del testamento y en el codicilo una curiosa cláusula de seguridad, que declara haber utilizado también en sus anteriores documentos de última voluntad. Ésta consiste en la inserción del texto latino del salmo Deus altissimus iustorum protector ${ }^{74}$. Expresamente advierte Ruy Díaz que ningún documento de última voluntad que no contenga de bervo ad bervum el citado salmo, pueda considerarse válido, porque no poniéndolo, será señal que o no estoy

72 ASIL, S.a 258-18, s.f.

${ }^{73}$ El derecho para testar y transmitir bienes estaba vedado a judíos, herejes y locos según las Partidas VI, tit. I, ley 1 y tit. XXVI, ley 4, y por ello era tan obligatoria la expresa declaración de cordura, como la profesión de fe.

74 Agradecemos a la doctora $\mathrm{M}^{\mathrm{a}}$ Asunción Sánchez Manzano la ayuda para identificar el salmo que corresponde al 90 de la Vulgata. 
en mi sano juicio o me hazen hazer otorgar, por fuerça, a ruegos e persuasiones, $y$ poner lo que no quiero, ni tengo obligación, y assi para este efecto lo pongo.

Concluidas las cláusulas declaratorias, expone Ruy Díaz su nombre y filiación, así como la circunstancia de carecer de herederos forzosos, por haber muerto todos sus familiares directos, todo ello con la brevedad usual, para pasar a continuación a desgranar el conjunto de disposiciones bajo las que desea morir.

Comienzan éstas con la elección de la mortaja y del lugar del enterramiento. Nuestro leonés dispone que, de morir en Panamá, se le inhume con el hábito de san Francisco y en el convento de esta Orden. Y como allí falleció, hemos de suponer que en ese convento, comenzado a edificar en la principal calle Carrera allá por 1573 , sería donde recibiría sepultura ${ }^{75}$. Quedaría así incumplido el deseo de su esposa, de que su cuerpo reposase junto al de su marido ${ }^{76}$, porque el coste y las dificultades que entrañaba el traslado de restos mortales desde el otro lado del Atlántico, hacía inviable su enterramiento en tierras leonesas. La elección del convento de San Francisco era, por lo demás, muy lógica, dadas sus vinculaciones familiares y personales con la Orden, a la que pertenecía su confesor, fray Alonso, del que lamenta no recordar más que el nombre, y fray Gabriel de la Soledad, estante en ese tiempo en España, al que ordena entregar mil reales para el efecto que le tiene comunicado, disposición que refleja un alto grado de confianza ${ }^{77}$. Precisa Ruy Díaz el deseo de que su sepultura se disponga pegada a la pila del agua bendita, porque de aquel regato de aquel agua bendita que se derramare cayga sobre él, porque baya de alli todo el espiritu malo. Era por entonces el convento e iglesia de los seráficos un humilde edificio de madera, y consciente de ello, Ruy Díaz pide que, caso de ser enterrado allí, se entreguen 500 pesos para que se haga e empiece a hazer la capilla mayor de piedra e ladrillo, porque el Santísimo Sacramento esté más guardado e con más desensia. La iglesia, sin embargo no comenzaría a labrarse de cantería hasta 1603, en tiempos del guardián Pedro Gutiérrez Flores, con un presupuesto superior a los 40.000 pesos, cantidad que reduce a gesto exiguo el legado del leonés ${ }^{78}$.

${ }^{75} \mathrm{M}^{\mathrm{a}}$ del C. Mena (1992), La ciudad en un cruce..., pp. 164-174.

${ }^{76}$ AHN, NoBLEZA, Fernánnúñez,leg. 683/7.

${ }^{77}$ Fray Gabriel de la Soledad había venido a España, contando con cartas de recomendación del arzobispo Toribio Alfonso de Mogrovejo, a gestionar la facultad real que le permitiese fundar conventos de recolección franciscana. AGI, Patronato 248, R. 22.

${ }^{78} \mathrm{M}^{\mathrm{a}}$ del C. Mena (1992), La ciudad en un cruce..., pp. 164-174. 
Acerca de sus honras deja establecido que el día de su entierro, guíe su cuerpo la cruz y el rector de la iglesia parroquial, sin más acompañamiento que el de un grupo de pobres mendigos -hasta cincuenta-, a los que se deberían abonar 4 reales, para que rogasen por su alma, y se le diga una misa cantada de cuerpo presente, si es hora para ello, con la limosna y la ofrenda de pan y vino acostumbradas. Para el día del sepelio y los dos sucesivos, dispone que se avise a todos los frailes y curas del lugar para que le digan todas las misas posibles, con sus responsos correspondientes. Para garantizarse un tránsito breve por el purgatorio deja encargado que, en el convento donde recibiere sepultura, se le digan tres misas rezadas diarias durante el año siguiente a su óbito, con responsos sobre su sepultura, la una por el ánima a quien más obligación tengo de haser bien, y la otra por el ánima que más cerca estuviere de salir del purgatorio, y la otra por el ánima que más desamparada estuviere e más falta de quien le haga bien. Como era habitual entre los que en la época podían permitírselo, la disposición de sufragios, incluye también una memoria de misas perpetuas, pero éstas en su tierra natal, en el convento de San Isidoro, donde todos los días del mundo se le han de decir dos misas rezadas, con la oración Deus qui justificas impium ${ }^{79}$,responso y salve cantada; todo ello aplicado por su alma y por la de las personas a las que hubiese infringido algún daño, asi de hazienda como de afrentas o malas palabras... y a todos mis bienhechores, y a mis abuelos y suegra y a María García, porque dexó por heredera a Antonia, mi hija. Salves y misas habían de oficiarse en la capilla que él llama de Nuestra Señora de la Transfiguración, y sitúa frontero de la puerta de la iglesia que es la puerta menor.

No conocemos ninguna advocación mariana unida al episodio de la Transfiguración, que corresponde exclusivamente a Cristo, y nos extraña la confusión, porque el manejo de salmos y oraciones de Ruy Díaz nos hace pensar en una persona con formación religiosa suficiente como para no incurrir en errores de este tipo. Tal vez los años de lejanía propiciaran un lapsus linguae y quisiera referirse a la de la Santísima Trinidad, misterio hacia el que por las cláusulas declaratorias parece mostrar especial devoción y que era la advocación titular, en el siglo XVI y XVII, de la capilla románica de ladrillo, abierta al norte de la cabecera del templo ${ }^{80}$; igualmente podría ser cualquiera de las de titularidad mariana, del

${ }^{79}$ Se refiere a la oración: Deus, qui iustificas impium et non vis mortem peccatorum Maiestatem tuam suppliciter deprecamur, ut hunc famulum tuum, de tua misericordia confidentem, caelesti protegas benignus auxilio, et assidua protectione conserves, tu tibi iugiter famuletur, et nullis a te tentationibus separetur. Per Christum Dominum nostrum Amen. (Missale Tridentimun. Orationes Diversae, $n$ 24. Pro tentatis et tribulatis).

80 J. Pérez Llamazares (1982), Historia de la real colegiata..., pp. 376-377. 
claustro: la de la Inmaculada Concepción, misterio defendido con especial tenacidad por la Orden y la espiritualidad franciscana, y muy venerado por los Quiñones, cuya propiedad detentaba en la Edad Moderna el regidor Fernando Castañón; la de la Asunción, advocación muy arraigada entre los leoneses por ser la titular de las grandes fiestas de la ciudad, de la que fueron propietario los Villafañe; o la de la Invocación de Nuestra Señora, anteriormente conocida como la de San Pelayo, y después como la de los Inclanes, por la familia a la que perteneció en el siglo XVII ${ }^{81}$.

Más preciso que en la designación de la capilla se muestra Ruy Díaz a la hora de concretar el horario de la eucaristías y los gajes que han de corresponder a los canónigos asistentes a las salves. Las misas habían de decirsea las 7 y a las 10 de la mañana en verano y a las 8 y las 11 en invierno, correspondiendo al presbítero que las dijera dos reales por cada una; en el canto de las salves habían de participar cuantos canónigos pudiesen, con velas encendidas en la mano, repartiéndoseles por su asistencia medio real a cada uno, excepto al prior, que recibiría un real, y al abad, que, de hallarse presente, recibiría cuatro reales. Aún dispone otra misa, esta cantada, con responso y vigilia, para decir en la víspera de una de las cinco fiestas de Nuestra Señora -Purificación, Anunciación Asunción, Natividad e Inmaculada-; ese día habían de distribuirse los 300 ducados de renta que legaba a la comunidad isidoriana.

A la disposición de misas se suma el mandato de que se tome por su alma una bula de composición. Se trataba de un tipo de bula de la cruzada, que tenía la peculiaridad de absolver a sus compradores del pago de hasta 30 ducados, sobre cualquier clase de bienes y haciendas conseguidas de forma "poco ortodoxa", siempre que no tuvieran certeza de a quien correspondía su restitución. La tasa habitual era de 12 ducados, pero la cantidad destinada a garantizarse la tranquilidad de conciencia de Ruy Díaz es nada menos que de 200 ducados, lo que cabe interpretar como un implícito reconocimiento de cierta falta de honradez en sus transacciones mercantiles ${ }^{82}$.

El mismo carácter de sufragio redentor que bulas y misas, tenían las mandas pías o legados de caridad. Las primeras a las que hace referencia el testamento de Ruy Díaz son a las conocidas como forzosas, que incluían la limosna para el

81 J. PÉRez Llamazares (1982), Historia de la real colegiata..., pp. 397-398 y ArChivo General De Simancas, (en adelante AGS), Patronato Eclesiástico, Leg. 277, ff- 90r, 91v y 92.

${ }^{82}$ Algunos datos sobre la bula de la cruzada en Indias pueden verse en L. LOPETEGUI y F. Zubillaga (1965), Historia de la Iglesia en la América Española, Madrid, Biblioteca Autores Cristianos, pp. 33, 69 y 70. 
mantenimiento de los Santos Lugares, particularmente del Santo Sepulcro, y para la redención de cautivos. Nuestro leonés asigna a cada una nada menos que 10 pesos, cantidad realmente generosa, si tenemos en cuenta, por ejemplo, que el gobernador nicaragüense Pedrarias Dávila se limitó a señalarlas 30 maravedíes ${ }^{83}$.

Los legados voluntarios señalados tanto en el testamento como en el codicilo parecen dictados por la caridad, el agradecimiento y el afecto. El llamado a beneficiarse en primer lugar de la generosidad de Ruy Díaz es el hospital del lugar en que muriese, para el que deja 200 pesos para adquirir ropa de cama; el legado iría al de San Sebastián de Panamá, cuyos orígenes se remontan a 1521, y que, aunque había mejorado sensiblemente su fábrica desde 1585, seguía padeciendo una crónica insuficiencia de rentas, que sólo podía paliarse gracias a la limosna de los vecinos ${ }^{84}$

También las cofradías y los conventos panameños fueron objeto de legados. En el momento de la redacción de sus últimas voluntades, aunque ya se habían iniciado las gestiones para la fundación de un convento femenino bajo la advocación de la Inmaculada Concepción ${ }^{85}$, no existían sino cuatro comunidades masculinas: la de san Francisco, a la que deja los mencionados 500 pesos para su capilla mayor; la de la Merced, llegada en 1522; Santo Domingo, cuyo convento había fundado en 1571 fray Domingo Pérez; y la Compañía de Jesús, con presencia desde 1578; a todas ellas las lega una limosna de 50 pesos $^{86}$. Manda distribuir 10 pesos entre las cofradías catedralicias del Santísimo Sacramento, de las Ánimas del Purgatorio y de Nuestra Señora del Rosario. Las dos primeras figuran, en efecto, entre las que tenían instituidas misas en la iglesia mayor, pero no así la tercera; las dos únicas cofradías marianas de cuya existencia en la catedral tenemos constancia, son las de la Concepción y las de Nuestra Señora de la O, ambas con altares

83 Pedrarias Dávila había otorgado su testamento en 1530, más de seis décadas antes que Ruy Díaz, pero la distancia temporal no anula la abismal diferencia entre su legado, que no llega al real, y el de Ruy Díaz, que alcanzaría los 90 reales, considerando el valor de cada peso corriente en 9 reales, que es la equivalencia usada en su testamento. Sobre las últimas voluntades del testamento del gobernador remitimos a $\mathrm{M}^{\mathrm{a}}$ del C. Mena (2004), Un linaje de conversos en tierras americanas (Los testamentos de Pedrarias Dávila, Gobernador de Castilla del Oro y Nicaragua), Universidad de León, especialmente pp. 155-185.

${ }^{84}$ Sobre el hospital de San Sebastián: Ma del C. MenA (1992), La ciudad en un cruce..., pp. 186193

${ }^{85}$ Acerca de la fundación del monasterio Concepcionista y el impulso dado a ella por Francisco Terrín a partir de 1597: P. HeRnÁNDEZ APARICIO(1990), «Primer convento de las concepcionistas de Panamá», La orden concepcionista. Actas del I Congreso Internacional, vol. I, León, pp. 555-562.

${ }^{86}$ Sobre estos centros religiosos: $\mathrm{M}^{\mathrm{a}}$ del C. MENA (1992), La ciudad en un cruce..., pp. 174-176. 
propios; además la advocación del Rosario es más propia de las iglesias de la Orden de Predicadores ${ }^{87}$.

En León, dejando al margen las mandas que tienen a San Isidoro como receptor, fueron objeto de la caridad de Ruy Díaz, el convento de San Francisco, al que lega 100 ducados para que se le digan las misas que considerasen oportunas, y su guardián, al que nombra por albacea para los bienes de esta tierra, señalándole como agradecimiento un hábito entero; evoca también a la Virgen del Camino, para cuya ermita manda se haga una lámpara de plata de 100 ducados de coste; aunque el legado más sustancioso es para la parroquia de San Pedro, sita en la misma iglesia de San Isidoro. En ella deja fundada una memoria destinada a solemnizar el culto al Santísimo, cuando éste fuera sacado en procesión. La fundación incluía la elaboración de un palio con seis varas de plata, un guión con cruz y barra de plata y 7 ropas de mozos de coro con otros tantos sobrepellices; siempre que se procesionase, habían de portar el palio y guión, clérigos con sobrepellices, y seis muchachos, revestidos con las ropas de coro deberían ir alumbrándolo, y otro más anunciando su paso con campanilla; su salida y entrada en la iglesia había de ser celebrada con toques y repiques de campana; los participantes recibirían a razón de un real el portador del guión, medio los de las varas, 8 maravedíes cada muchacho, un real el cura que llevase el Santísimo, y otro el campanero; todo con condición de que al entrar el cortejo se evocase su nombre y se rezasen tres pater noster y otras tantas avemarías, por su alma y por el estado y felicidad de la Santa Madre Iglesia Cathólica Romana y por la reducción de los erejes y gentiles infieles a la santa fe católica y obediencia de la Santa Madre Iglesia.

En un tiempo y en un ámbito donde los lazos de sangre eran tan esenciales, los legados a la familia eran capítulo ineludible en todo testamento. Cuando Ruy Díaz redacta sus últimas voluntades ya conocía el fallecimiento de sus padres, esposa e hijos, pero no tenía noticia de la suerte corrida por otros familiares cercanos, como sus hermanas. A ellas va dirigido su primer recuerdo: a Ana, monja en Santa Clara de Astorga, le deja 100 ducados, y a Francisca, profesa en el convento vallisoletano de Belén, 150, con la advertencia de que si hubiesen fallecido, debían de emplearse en misas por su alma, a oficiar en la iglesia donde él hubiese recibido sepultura. Hace memoria asimismo de algunos Quiñones, aunque sin precisar el grado de parentesco que le unía con ellos; así, a Pedro, escribano en León, el mismo al que

${ }^{87}$ Las citadas cofradías aparecen mencionadas en la Relaciónde 1607: P. de VALENCIA, Relaciones de Indias 1. Nueva Granada y Virreinato de Perú, en Obras completas V, ed. J. PANIAGUA PÉREZ (1993), p. 189. 
había confiado las cuentas de sus rentas en estas tierras y ante el que se había formalizado el testamento de Ana, su mujer, le deja 200 ducados, considerando con ello satisfechos todos sus servicios y compensados los posible adeudos; y a Pedro Bernardo de Quiñones, estante en Panamá en 1595, 300 pesos como ayuda para trasladarse al lugar a donde decidiese.

Más numerosas son las mandas destinadas a criados y conocidos. La gratitud y el afecto mueven a Ruy Díaz a dejar a su criado Luis Mella, mulato dominicano, 50 pesos, y a otro servidor, oriundo de Ciudad Real, llamado Diego López, una barra de plata. En su codicilo hace mención también de una criada negra, María Vélez, a quien ordena entregar 20 pesos a mayores del salario que le adeudare, y de Clara García, su casera, para la que destina el coste de un manto nuevo y bueno, por los regalos que le a hecho. Con especial interés parece tomarse la liberación de una esclava conocida como Elena Bran; al tiempo de redactar el testamento dice ser propiedad de Mariana Ramírez de Quiñones, esposa de Armas Perdomo, y en ese momento deja 300 pesos para su manumisión; cuando la vuelve a mencionar en su codicilo, afirma que había sido esclava de Juana de Quiñones y entonces lo era de Juana de Ribero, esposa del regidor Delgadillo, a la que confiesa haber hecho una obligación por valor de 150 pesos por una deuda inexistente, que en realidad encubría un compromiso de pago para conceder la libertad a la citada esclava, a la que ordena se le entreguen 50 pesos más como contribución a ella. Asimismo hace donación de otros 50 pesos para ayuda de la manumisión de otra esclava llamada María Castilla, propiedad de un tal Gonzalo Vázquez.

Especial consideración demuestra hacia el licenciado Torres, abogado en la Real Audiencia de Panamá ${ }^{88}$, al que lega 300 pesos, por lo que a travajado en mys pleitos y por la voluntad con que siempre a acudido a mis cosas. También hacia el padre Luis de la Parra, que probablemente había fallecido en Tierra Firme, al que recuerda con una manda de 160 reales, para repartir en limosna o destinar a misas por su alma. Y asimismo hacia la hija de Juana de Quiñones y Pedro López de Baeza, a quien pese a sus diferencias contables, se muestra dispuesto a legarle 1.000 pesos. Igualmente afectuoso parece hacia María García, también difunta, que había servido en casa de su suegra, Leonor de Quiñones, y que debió ser la persona encargada de criar a su hija Antonia, a la que incluso había dejado como heredera;

${ }^{88}$ No hemos localizado ninguna referencia sobre este licenciado que en el testamento aparece citado, como albacea y beneficiario del citado legado, con el nombre de Alonso, aunque el encargado de pedir la apertura del testamento y el que como testamentario da cuenta de la herencia al convento de San Isidoro firma y se presenta como Gaspar de Torres. 
por todo ello, dispone se le digan 250 ducados en misas allí donde sus albaceas leoneses señalaren.

No se agotan con los hasta aquí relacionados los legados píos dispuestos por Ruy Díaz, pues aún falta reseñar el de mayor alcance social: el establecimiento de un pósito en Corbillos de la Sobarriba. Era ésta una institución de crédito y previsión social, regulada por pragmática de 15 de mayo de 1584, que alcanzó una densa implantación en Castilla y León y pasó a América en el último cuarto del siglo XVI. Aunque en muchos casos los pósitos nacieron a iniciativa comunal o concejil, no fueron raros los casos en que surgieron de la generosidad de fundadores particulares. Los ejemplos de emigrantes que, conscientes de la gravedad de las periódicas crisis de subsistencia que sufrían sus lugares de origen, deseaban contribuir a soportarlas dejando rentas para instituir pósitos, son abundadísimos, como puede comprobarse con una simple cata de la documentación de Bienes de Difuntos, correspondiente a la última década del siglo XVI y primera del XVII ${ }^{89}$. Ruy Díaz, en sintonía con esta tendencia, dispone que su heredero adquiera 40 cargas de trigo, 30 de cebada y otras tantas de centeno, para depositarlas en una panera hecha al efecto, cuyo coste sufragaría a medias con el concejo, en el lugar de Corbillos de la Sobreriba, una legua de León, donde yo e mi padre y abuelo emos tenido e tenemos hazienda. Las reglas fijadas eran las habituales ${ }^{90}$ : el depósito de grano más 100 ducados en dinero, deberían estar custodiados bajo tres llaves, que estarían en poder de su heredero, del titular de la casa y hacienda que el fundador tenía en el lugar, y del vecino que anualmente

${ }^{89}$ Valgan como prueba algunos ejemplos tomados de la citada sección del AGI: en 1592, Juan Martínez Rojo, natural de La Vid (Burgos), dejaba fundado en su localidad una capellanía, en la Iglesia de San Juan, y un pósito (Contratación, 486, N1, R. 10); en 1597, el licenciado Juan Alcedo de la Rocha, también burgalés, instituía diversas fundaciones para enseñar a leer, casar huérfanas, y, entre ellas, en el pueblo de Villafría, un pósito de trigo y limosna de pan (Contratación, 927); en 1601, Alonso Martínez Balconate, natural de Fresno de Torote, en Guadalajara, dejaba bienes para que en su patria chica se fundaran dos capellanías, un pósito de grano y un preceptoría de gramática (Contratación, 494); en 1605, Francisco de Cozar, natural de la Calzada, legaba a su patria rentas para una capellanía y para constituir un patronato de dotes, pósito y manutención de dos estudiantes (Contratación, 498); y en 1609, Juana de Quirós, natural de Aguilar (Valladolid), agregaba a la capellanía instituida por su padre, un pósito y un hospital (Contratación, 514).

${ }^{90}$ Sobre el papel de los pósitos en época Moderna: J. LÓPEZ YePES (1971), Historia de los Montes de Piedad de España, Madrid, Confederación Española de Cajas de Ahorro; F. RuIz MARTín (1970), «La banca en España hasta 1782» en El Banco de España. Una Historia económica, Madrid, Banco de España; Ma del C. Fernández HidAlgo y M. GARCía RuipÉREZ (1989), Los pósitos municipales y su documentación, Madrid, Asociación Española de Archiveros, Bibliotecarios, Museólogos y Documentalistas; y P. CARASA SOTO (1991, Historia de la beneficencia en Castilla y León. Poder y pobreza en la sociedad castellana, Valladolid, Universidad de Valladolid, pp. 147-151. 
designase el Concejo; su finalidad era actuar como institución crediticia, prestando sin interés alguno, para, de ese modo, actuar de efectivo seguro de los pequeños productores agrícolas, al salvarles de la usura en tiempos de escasez de simiente. Las condiciones del crédito eran sencillas. Levantadas las eras, el vecino que le faltare grano podía pedir un préstamo al pósito; las solicitudes se resolverían en septiembre u octubre, el día que los tenedores de las llaves señalaren, después de celebrada una letanía y misa en memoria de Ruy Díaz y por el aumento de la santa fe y paz entre los reyes y príncipes cristianos y reducción de los erejes ynfieles a la santa fe católica; para evitar especulaciones, solamente podrían acceder a la ayuda, aquellos labradores que tuvieran bueyes y tierras, en propiedad o arrendamiento, para cultivar; las cantidades prestadas y el nombre de los beneficiarios debían anotarse en un libro-registro, que, firmado por tres testigos, adquiriría categoría de documento público; el deudor debía dar fianzas suficientes de que devolvería el grano al año siguiente, antes de Nuestra Señora de Septiembre, de lo mejor de su siguiente cosecha; el impago o retraso sería penalizando excluyendo al moroso de la posibilidad de nuevas ayudas por espacio de dos años; en caso de que hubiese más solicitadores que posibilidad de ayuda, la mayoría de votos de los depositarios de las llaves decidiría qué peticiones deberían ser atendidas, y por el contrario, si sobrase grano, la ayuda podía abrirse a vecinos de lugares cercanos a Corbillos; en caso de que todavía hubiera sobrante, se debía vender para adquirir con lo procedido grano nuevo. En cuanto al depósito de los 100 ducados, estaba pensado para solucionar las crisis de liquidez, porque muchos de los vecinos suelen, para segar su yerba y su pan, tener neçedidad de bender de su ganado y hazienda, por menos de lo que bale; en este caso el préstamo se decidía en un día fijado de abril o mayo, con las mismas solemnidades y requisitos que el del grano, salvo en lo que se refiere a la fecha de devolución, que había de ser el primer domingo después del señor Sant Andrés del mismo año, porque ya entonces an hecho dinero en las ferias de lo que crian e tienen para bender.

La necesidad de afrontar la muerte a salvo de cualquier preocupación material impone que en todo documento de última voluntad se dedique una parte a señalar el estado de los bienes y rentas del testador, en que entra la relación de deudas a favor y en contra. Su obligada mención no significa que sea éste el soporte idóneo para detalles y precisiones, pues, como ocurre en el testamento y codicilo de Ruy Díaz, suele haber más alusiones indirectas a escrituras y libros de cuentas, y a recomendaciones de que sus albaceas ajusten cuentas pendientes con determinadas personas, que datos concretos.

Ya nos hemos referidos a algunas de las propieda desde nuestro leonés -las casas de Panamá y Nombre de Dios, el lanchón del Chagres- y algunas de sus fuentes de ingresos y sociedades, incluidos los trajines con esclavos y bergantines 
en las pesquerías de perlas. De manera que nos limitaremos únicamente recordar algunas otras rentas y bienes con los que cuenta como base económica para sus legados y fundaciones. Como ya comentamos, en su haber anota Ruy Díaz una serie de herencias de las que era beneficiario: la de su tío Pedro Ramírez, cuyos bienes paraban en Sevilla en poder del mercader Antonio Rodríguez o del solicitador Francisco Martínez, y que en ningún momento cuantifica; la de Cristóbal Lebrón de Quiñones, clérigo, que se había criado en Santo Domingo, en cuya Audiencia había sido oidor su abuelo, y del que no se especifica el parentesco ni la cuantía del legado, aunque sí algunas obligaciones pendientes con su alma, para el cumplimiento de las cuales, dispone se empleen 1.200 pesos, para saldar posibles deudas pendientes en La Española, decir mil misas rezadas por su alma en el monasterio Regina Angelorum, de monjas dominicas, y repartir el sobrante entre la catedral de Santo Domingo y el capitán Jerónimo de Agüero, como coherederos; y finalmente, la de su padre Diego, más la que le correspondió de la dote de su esposa, por haber muerto ya sus hijos, y la de su tía Juana Ramírez e don Antonio Ramírez my primo hermano, primero llamado que yo, difunto días ha, todas ellas en tierras leonesas. Desconocemos el monto exacto de éstas, aunque sí sabemos que de los bienes dotales de su mujer hubo de entregar al monasterio de Gradefes, además de la casa y viña de Corbillos, 37.000 maravedíes procedentes de juros sobre alcabalas, que estaban depositados en poder del canónigo Alonso Rodríguez de Lorenzana, en pago de los alimentos, dote y legítima pertenecientes a su hija Antonia, profesa en él; que unas casas que poseía en la calle Serranos, habían sido vendidas $^{91}$; y que según lo transmitido a su albacea y comunicado por éste a San Isidoro, en el momento de la muerte todavía contaba en León con casas principales y como 800 ducados de renta.

El testimonio del licenciado Gaspar de Torres es taxativo a la hora de señalar la existencia de posibles bienes no declarados en poder de particulares, principalmente del perulero sevillano Antonio Rodríguez de Cabrera, reconociendo que con ser él a quien más comunicó sus cosas, sabe muy poco de ellas, y creo -añade- que anduvo cuerdo en no declararse más, por los pleitos que con él trata el fiscal de Su Majestad.

El volumen del debe en las cuentas de Ruy Díaz, peca de la misma imprecisión y opacidad que sus bienes. Solicita en sus últimas voluntades se ajusten cuentas con Juan López de Baeza y su esposa, a la que reclama del orden de 4.000 pesos;

${ }^{91}$ Los datos sobre los bienes de los que tomó posesión el monasterio de Gradefes en septiembre de 1587, y las referencias a la casa vendida corresponden a ARCHV, PL. CIVILES, Pérez Alonso (F.), 1006.0003. 
considera que el oidor Alonso de la Torre, con el que mantiene el pleito por los bergantines, le debe más de 1.000 pesos, aunque parece dispuesto a perdonárselos y hasta entregarle 4 o 5 negros que había comprado en su nombre, con tal de llegar a un acuerdo al margen de los tribunales. Reconoce 1.300 pesos de deuda a favor de Mariana Ramírez de Quiñones, mujer de Arias Perdomo, con los que considera deben zanjarse todas las cuentas pendientes entre ellos. Ruega se salden también los débitos existentes con los escribanos Diego Castillo, Francisco Ortiz -unos 200 reales- y Núñez Bejarano - 80 pesos-. Pide asimismo que se arregle el alcance a su favor, que considera habrá generado el jaez, valorado en más de 10.000 ducados, que dio en prenda a Luis Osorio de Quiñones, a quien debía lo que parecerá por dos obligaciones. Ordena se paguen los 1.800 reales que dejó de deuda en León por las caballerías para su viaje. Y el resto de las enumeradas son ya deudas menudas: 13 o 14 pesos de resto de una cuenta mayor al regidor Damián Méndez, el alquiler vencido de su casa, el salario de su criada María Vélez, y algunos reales al sastre Pablo de Saquete y a Juan Domínguez.

El heredero elegido para tan confuso patrimonio sería el monesterio de señor santo Ysidro de León, al que, como era de obligación le fue comunicado por carta remitida por el testamentario Gaspar de Torres, a la que acompañaba copia autentificada del testamento y codicilo. La noticia se recibía el 20 de enero de 1598 y en el capítulo de 31 de julio, sus prebendados decidían a aceptarla, aunque a beneficio de inventario, lo que implica ya cierta desconfianza sobre la solvencia del testador, o por lo menos una comprensible cautela ante la maraña de pleitos en la que estaba encausado ${ }^{92}$. Aunque nada dice sobre las razones que le mueven a la elección, hay dos circunstancias que ayudan a comprenderla. La primera, el hecho de que San Isidoro albergara la parroquia de San Pedro, a la que pertenecían sus casas principales. La segunda, la histórica vinculación de los Quiñones con el monasterio isidoriano; ésta se remonta a 1388, cuando Pedro Suárez de Quiñones lo elige como lugar de enterramiento; se refuerza a principios del siglo XV, cuando Diego Fernández de Quiñones, merino mayor de Asturias, capitula con el abad don Fernando su condición de encomendero del citado monasterio y su derecho y el de sus sucesores a tener sepultura en él; $y$, aunque doña María de Toledo prefirió ubicar la capilla funeraria de la rama principal en el monasterio de San Claudio, a finales del siglo XVI, aún seguía sirviendo de última morada a la representada por

92 ASIL, Actas capitulares 1574-1600, I-e, 74-1b, f. 477r.. 
don Antonio de Quiñones, señor de la casa de los Cilleros, titular de la capilla hoy todavía conocida con el nombre del linaje ${ }^{93}$.

Toda la nebulosa confusión que envuelve a los bienes y rentas transmitidos, se trueca en meridiana claridad a la hora de señalar las cargas que comporta la condición de heredero. De las rentas y dineros existentes en la Península y del sobrante que quedare de los bienes de Panamá tras venderlos en almoneda y dar cumplimiento a las mandas y legados dispuestos para aquellas latitudes, el prior y capitulares de San Isidoro deberían de adquirir el grano y entregar el depósito monetario de la fundación de Corbillos, además de correr con la mitad del gasto de la construcción de la panera; tenían que costear el palio, guión, trajes de los mozos de coro y demás adherentes dispuestos para la saca del Santísimo de la parroquia de San Pedro. El remanente que quedase de esos pagos debería invertirse en juros, a fin de que de su renta se señalase una cantidad para el gasto de la procesión del Santísimo y se sostuviese la memoria perpetua de misas y salves establecida en la capilla isidoriana. Si el volumen de la renta fuese tal, que cumplidas estas obligaciones, aún sobrasen posibles, se debería beneficiar con 300 ducados al cabildo y su prior, y si aún quedase con qué, establecer una limosna de ayuda a una, dos o más huérfanas, para tomar estado, siempre gente recoxida e de buena vida y que en igualdad den esta limosna a la más noble.

Especial importancia reviste en un documento de última voluntad la designación de albaceas, pues pocos actos requieren una confianza mayor, ya que en ellos el testador no sólo deposita sus bienes materiales, sino su propia salvación, al ser ellos los encargados de asegurar el cumplimiento de los sufragios redentores. Precisamente por estas razones solía preferirse a familiares o amigos especialmente cercanos, y cómo Ruy Díaz era un hombre sin familia directa, hemos de presuponer que los designados son gente de su entorno más próximo y de relativa confianza, aunque como se desprende de las palabras de Gaspar de Torres, Ruy Díaz no debía ser hombre dado a las confidencialidades. Deseando facilitar la ejecución de sus disposiciones, nombrará testamentarios diferentes para los asuntos de Panamá y los peninsulares, e incluso dejará previsto cómo debería procederse en caso de que su muerte acaeciese en otro lugar: $Y$ si Dios fuere servido de llevarme en el Nombre de Dios u otro lugar de las Indias fuera de Panamá..., nombró al hombre más rico y abonado que obiere en el lugar que yo falleciere, salvo si se hallare presente alguno de los ya nombrados o estuvieren en el reyno que yo

93 C. Álvarez Álvarez y J. A. Martín Fuertes (1977), Catálogo del Archivo de los Condes de Luna ..., doc. 58; J. Pérez Llamazares , Historia de la Real Colegiata..., pp. 394-396 y E. DíAzJimÉNEZ Y MolledA (1978), Historia de los comuneros de León, León, Nebrija, pp. 50-55. 
falleciere. Para Panamá los designados son el licenciado Torres, abogado de la Audiencia, y por tanto conocedor "de oficio" de sus asuntos jurídicos, Antonio de Almaraz, del que únicamente nos dice que en ese tiempo era residente en Panamá, y el que fuere guardián del convento franciscano de la ciudad. Para las tierras leonesas elige al prior de San Isidoro, al guardián del convento de San Francisco y a doña Ana de Lorenzana, hija del comendador Lorençana, y esposa del regidor leonés Pedro de Villamizar. En el codicilo añade, sin alegar razón alguna, a Juan de Luque Cubides, que había sido provisor del hospital, tesorero y, en ese tiempo, era deán de la catedral panameña ${ }^{94}$. Entre las obligaciones de los testamentarios estaba la de presentar el testamento ante el juez competente, en este caso Fernando Arias y Ugarte, oidor nombrado por el Presidente de la Audiencia para actuar como juez de bienes de difuntos, en el plazo de un mes y ejecutarlo en el plazo de un año, aunque este lapso de tiempo era prorrogable en función de lo compleja que pudiese resultar su ejecución. Ruy Díaz, consciente de la dificultad que podía entrañar el cumplimiento de sus últimas voluntades, prorroga a dos años el tiempo de actuación para sus albaceas e impone un plazo de tres años para que los designados como tenedores de bienes -el licenciado Torres y Almaraz- ynbien a Castilla todo lo procedido de... [su]... hazienda.

\section{LA REALIDAD FRENTE AL DESEO}

A partir del análisis de las últimas voluntades de Ruy Díaz hemos ido conociendo su anhelo de garantizar su salvación con sufragios suficientes para acortar su tránsito por el purgatorio y de perpetuar su memoria, al igual que lo hacían sus coetáneos, dejando fundaciones benéfico-asistenciales dignas de recuerdo. En un periodo de recesión económica como el iniciado a partir de la catastrófica cosecha de 1573, que no tocará fondo hasta bien entrado el siglo $\mathrm{XVII}^{95}$, no hay duda que la fundación de un pósito de grano y un fondo crediticio como el dispuesto por nuestro leonés era una iniciativa encomiable, lo mismo que los deseos de socorrer huérfanas o de dignificar la presencia del Santísimo y sus fiestas, pues no en vano estamos enplena aceptación y desarrollo de las disposiciones tridentinas. Se trata ahora de ver si tales anhelos contaban con base suficiente para poder ejecutarse y convertirse en realidades. Para tratar de hallar una respuesta hemos de plantearnos primero si la relación entre los bienes y rentas legados y las cargas impuestas permite un saldo suficientemente positivo como

94 J. LóPez De Velasco (1971), Geografia y descripción Universal de las Indias, Madrid, Biblioteca Autores españoles, p. 172

95 L. RuBIO PÉREZ (1986), Producción agraria en la zona norte castellano-leonesa durante la Edad Moderna, León, Universidad de León, p. 162. 
para afrontarlas, y después, si se dieron las circunstancias necesarias para que el heredero pudiera alcanzar el patrimonio transmitido.

Ya hemos constatado la imposibilidad de concretar el volumen total de la fortuna de Ruy Díaz, y tampoco estamos en condiciones de poder precisar los gastos de honras y sufragios, pero sólo el coste de acompañamiento de pobres supondría 200 reales y la memoria de misas del primer año unos 2.190 reales $^{96}$, cantidades a las que habría de añadirse el coste de la mortaja y el enterramiento conventual, los derechos parroquiales, la ofrenda de pan y vino, y el gasto de las misas que se le dijeron el día del entierro y siguientes. A estos gastos de funeral, honras y exequias hay que agregar la suma de sus mandas y legados.

Las disposiciones destinadas a conventos e imágenes que se cuantifican, suponen entorno a 4.320 reales, a los que hay que añadir los 1.800 destinados al hospital y los 2.200 de la adquisición de la bula; todo ello arroja un saldo de 8.320 reales, en los que no entran los 90 reales dejados a cada manda forzosa, puesto que no concreta su número. Esta cuantía se ve notablemente incrementada con las cantidades donadas a sus familiares, amigos y criados, que suponen unos 22.440 reales, sin el coste de la barra de plata dejada a su criado, ni el del manto de su casera.

Lo computado asciende ya a la respetable suma de 30.760 reales, cifra que no es sino una parte, aunque sin duda significativa, del gasto y carga que pende sobre sus bienes, lastrados además por una deuda reconocida superior a 25.000 reales.

¿Era la herencia suficiente para hacer frente a tales desembolsos y poder atender además a las memorias y fundaciones dispuestas en su tierra de origen?. Nos aproxima a la respuesta lo que su albacea, el licenciado Torres, escribe a la comunidad de San Isidoro: Según la orden de su testamento paresce que dexó muchos bienes, y no en estas tierras, porque todo quedó en pleitos, y dineros ninguno dexó y lo que balieron los bienes muebles a valido muy poco y eso se a consumido en pagar deudas por mandamiento de la Real Audiencia y Chancillería que aqui reside y de otras justicias, de manera que aún por su ánima a sido poco lo que se a hecho ${ }^{97}$.

${ }^{96}$ El cálculo se ha hecho sobre la base de tres misas diarias, los 365 días y a dos reales por misa, que es la limosna estipulada para las que se le han de decir en la memoria perpetua que deja en San Isidoro.

${ }^{97}$ ASIL, S. a 258-18. 
¿Era Ruy Díaz un soñador que se dejó llevar por la fantasía a la hora de disponer mandas y distribuir bienes de una fortuna inexistente? El cuidado con que parece llevar sus libros de contabilidad, que reiteradamente asegura tener puestos al día, nos hace dudar de esa posibilidad. Es seguro que su hacienda hubo de sufrir las luctuosas consecuencias del paso de Drake por Nombre de Dios en 1596 y que en el incendio de la ciudad es posible que perdiera la casa y, tal vez el lanchón, con el que trajinaba por el Chagres, pero la causa de la volatilización de su hacienda indiana hay que buscarla en otras razones.

En la disposición de sus voluntades, el leonés se nos revela como un hombre un tanto suspicaz y buen conocedor de los "peligros" inherentes a los negocios que desarrollaba en aquellas tierras, por eso, para salvaguardar sus bienes de posibles acciones judiciales, no tenía todos declarados ni en su poder. De esta parte daría cuenta la codicia de sus socios, sobre la que advierte el licenciado Torres al convento de San Isidoro, aconsejando que enbie para todo remedio, una paulina muy agravada y la absolución de Su Santidad reservada, para que todos los que tubieren bienes del dicho difunto los manifiesten, al tiempo que pone en duda la eficacia del remedio, según son por acá plegadas las conciencias para ponerse en sanctas. La hacienda declarada a su nombre sería devorada por acreedores y litigantes, porque, o bien se vio envuelta en causas cuyas costas eran más elevadas que las rentas que se dirimían, como era el caso del litigio con el oidor Alonso de la Torre, en el que ambas partes llevaban gastados más de cincuenta mil ducados, para un principal de unos veinte mil; o bien estaba afectada por pleitos en los que, aun habiendo sentencia favorable, no a de aver de qué cobrar ${ }^{98}$.

En consonancia con el panorama descrito, no es raro que no hayamos localizado ningún registro propiedad de Ruy Díaz en la Casa de Contratación de Sevilla, encargada de la custodia de los bienes de los fallecidos en Indias, lo que parece ratificar qué nada había que enviar de la fortuna habida en Panamá ${ }^{99}$. Así pués, sólo los bienes peninsulares, quedan para hacer frente a las disposiciones sobre la fundación del pósito de Corbillos, la memoria de misas en San Isidoro, la fundación en honor del Santísimo en la parroquia de San Pedro, las rentas para los capitulares isidorianos y la posible limosna de huérfanas. Parte de éstos paraban en Sevilla, en manos del perulero Antonio Rodríguez Cabrera y otra parte en tierras

98 ASIL, S. a 258-18.

${ }^{99}$ La normativa sobre los bienes de difuntos se recoge en la Recopilación Leyes de Indias, libro II, tit. 32 y libro IX, título 14. Sobre el procedimiento administrativo que se seguía: F. GUTIÉRREZAlviZ Y ARMARIO (1951), «Los bienes de difuntos en el Derecho indiano», en Anales de la Universidad Hispalense,IV-3, pp. 43-70. 
leonesas, donde se aseguraba conservaba sus casas principales y hasta 800 ducados de renta. Parece que el cabildo isidoriano confiaba sobre todo en las posibilidades de la hacienda que pudiera haber en Sevilla a la hora de asumir su condición de heredero, pero hemos revisado sus actas capitulares hasta 1610, la documentación conservada sobre la parroquia de San Pedro y la visita realizada en 1692 por Gandarilla a las capillas y misas instituidas en el convento de San Isidoro, sin hallar nuevas referencias a Ruy Díaz, su herencia o sus pretendidas fundaciones. Tal silencio no puede apuntar sino a la volatilización de la fortuna y consiguiente imposibilidad de cumplir con sus mandas testamentarias.

El analizado es un simple ejemplo de lo que sospechamos es una realidad más general, que vendría avalada con otros casos, como el del obispo de Nicaragua Valtodano y su pretensión de fundar una capellanía en el monasterio de San Claudio, que cuarenta años después de instituida, aún no había podido materializarse, porque los bienes dotales se hallaban perdidos en una maraña de causas que no hacían sino adelgazarlos y "evaporarlos" $"$. Creemos, en consecuencia, que conviene empezar a tomar con más cautela y menos literalidad la voluntad de "los indianos" de fundar, dotar y legar, porque entre la manifestación del anhelo y su realización, media tanta distancia como la que el refranero castellano pone entre el "dicho" y el "hecho"

${ }^{100}$ La figura del obispo Valtodano, su biblioteca y la fundación de la capellanía en el monasterio leonés, del que él mismo había sido abad, está siendo objeto de estudio y confiamos en verlo ultimado en pocos meses. 